\title{
OPEN A facile and efficient method for the synthesis of crystalline tetrahydro- $\beta$-carbolines via the Pictet-Spengler reaction in water
}

\author{
Hong-Ju Byeon ${ }^{1}$, Kyung-Hwan Jung ${ }^{1}$, Gi-Seong Moon ${ }^{1}$, Sung-Kwon Moon ${ }^{2,3^{*}}$ \& \\ Hyang-Yeol Lee $\mathbb{D}^{1,3^{*}}$
}

\begin{abstract}
A facile and efficient synthesis of tetrahydro- $\beta$-carbolines (tryptolines) in one step from tryptamine and aldehydes, in an environmentally friendly water solvent, has been investigated. This convenient and clean synthesis of various tryptolines was facilitated by L-tartaric acid, a natural compound, to obtain the desired products as clear crystals. Among the four crystalline products, the most substituted tryptoline 2 showed the best inhibitory activity against EJ cells and the least cytotoxicity, with an $\mathrm{LC}_{50}$ value of $1.49 \mathrm{mg} / \mathrm{mL}$, against brine shrimp larvae.
\end{abstract}

\begin{abstract}
The tetrahydro- $\beta$-carboline (tryptoline) moiety in the products of the Pictet-Spengler reaction has been observed in various synthetic and natural compounds. Tryptolines have been known to have many pharmacological and biological activities such as antimicrobial, antitumor, antiviral, and anticonvulsant activities, which has led to increased interest in the synthesis of these compound $\mathrm{s}^{1-4}$. Enantioselective tryptolines would be important for accessing useful chiral building blocks in complex alkaloid synthesis ${ }^{5}$. A number of enantioselective synthetic methods have been reported. Chirality can be introduced to the desired product by using asymmetric reduction methods using Noyori-type catalysis ${ }^{6}$. Better success has been achieved with Brönsted acid catalysts. Asymmetric catalysis of tryptoline products has been developed with $\mathrm{N}$-acyliminium ions ${ }^{7}$ or $\mathrm{N}$-sulfenyliminium ions $^{8}$. More recently, chiral thiourea derivatives in combination with benzoic acid promote catalytic asymmetric Picted-Spengler reaction to provide unprotected tryptolines in high ee and yield ${ }^{9}$. However, most of the reported synthetic methods require organic solvents and expensive or hazardous catalysts ${ }^{10-12}$. Thus, the use of organic solvents in industrial organic reactions is limited because the presence of water in these solvents often results in low yields of the products and/or low reaction rates. Moreover, due to concerns over human health and the environment, environmentally friendly reactions have attracted greater attention from the viewpoint of green chemistry as compared to chemical processes that use organic solvents and toxic reagents. Thus, aqueous reactions are desirable since water is the safest and most inexpensive green solvent ${ }^{13-16}$. Aqueous reactions for the Pictet-Spengler cyclization are known, but they require harsh conditions or a large excess of strong acid catalysts. A variety of efficient catalytic systems, especially those based on Lewis or Brönsted acids, have been developed for these aqueous reactions, but most of the systems are expensive or hazardous ${ }^{7,17-19}$. Moreover, the products formed are racemic mixtures ${ }^{20}$.

In this study, we report a naturally abundant compound, L-tartaric acid, which facilitates the aqueous Pictet-Spengler reactions and affords the products as colorless crystals. L-tartaric acid facilitates the formation of the desired tryptolines 1-4 under mild conditions, in the absence of an organic solvent. This new method using water and L-tartaric acid is safe, inexpensive, and easy, and the tryptolines can be conveniently isolated by simple filtration as they are formed as crystals. The anticancer activity of tryptolines 1-4 against EJ cells was investigated, and their cytotoxicity was determined by the brine shrimp lethality assay ${ }^{21}$.
\end{abstract}

\footnotetext{
${ }^{1}$ Department of Biotechnology, Korea National University of Transportation, 61 Daehak-ro, Jeungpyeong-gun, Chungbuk, 27909, Republic of Korea. ${ }^{2}$ Department of Food and Nutrition, Chung-Ang University, 4726 SeodongDaero, Daedeok-Myeon, Anseong, 456-756, Republic of Korea. ${ }^{3}$ These authors contributed equally: Sung-Kwon Moon and Hyang-Yeol Lee. *email: sumoon66@cau.ac.kr; hyl@ut.ac.kr
} 

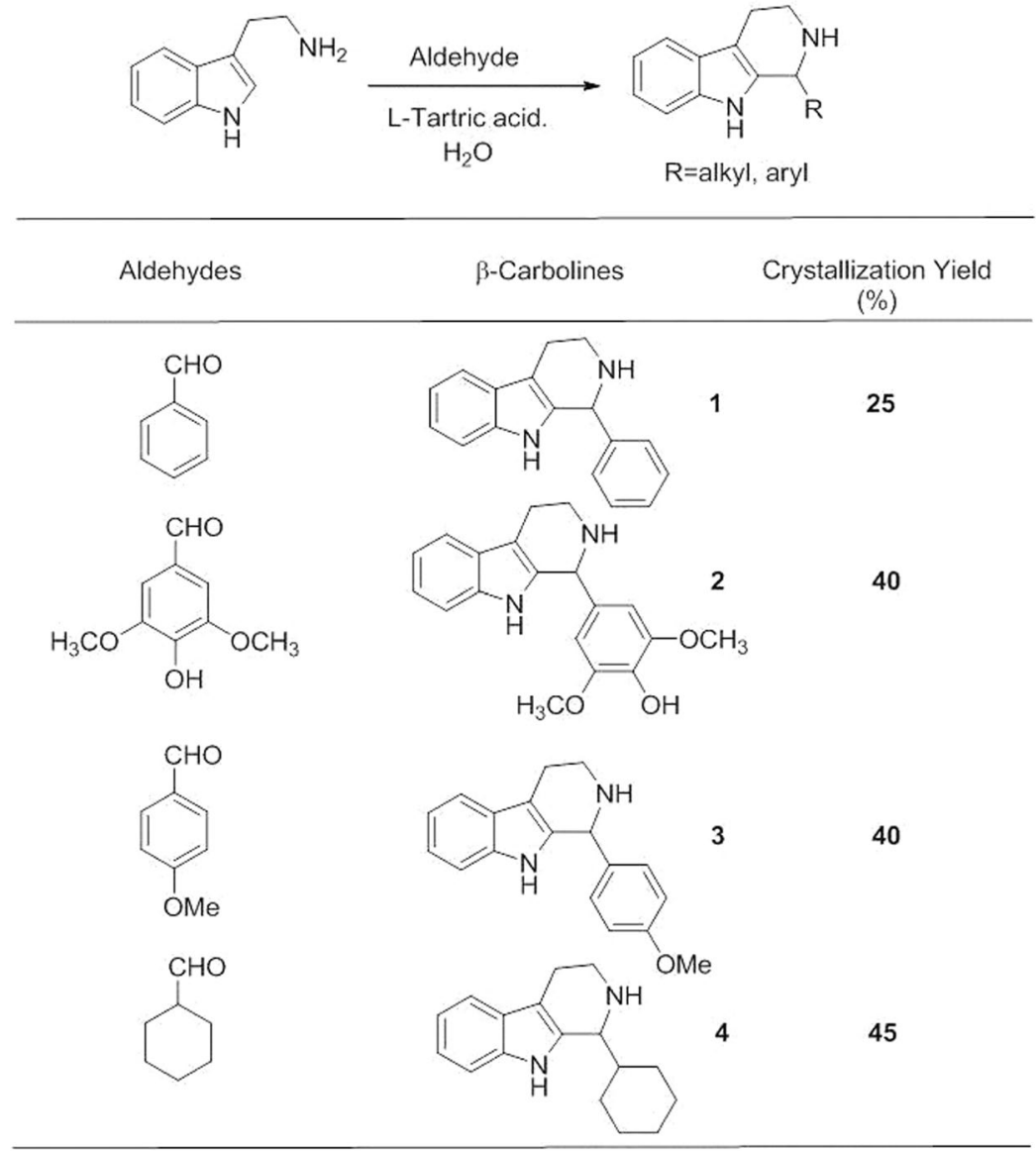

Figure 1. Scope of the aqueous Pictet-Spengler reaction using tryptamine and four different aldehydes facilitated by L-tartaric acid. (1) 1-phenyl-2,3,4,9-tetrahydro- $1 H$-pyrido[3,4- $b$ ] indole, (2) 2,6-dimethoxy-4(2,3,4,9-tetrahydro-1H-pyrido[3,4-b]indol-1-yl)phenol, (3) 1-(4-methoxyphenyl)-2,3,4,9-tetrahydro-1Hpyrido[3,4- $b]$-indole, and (4) 1-cyclohexyl-2,3,4,9-tetrahydro- $1 H$-pyrido[3,4- $b]$ indole.

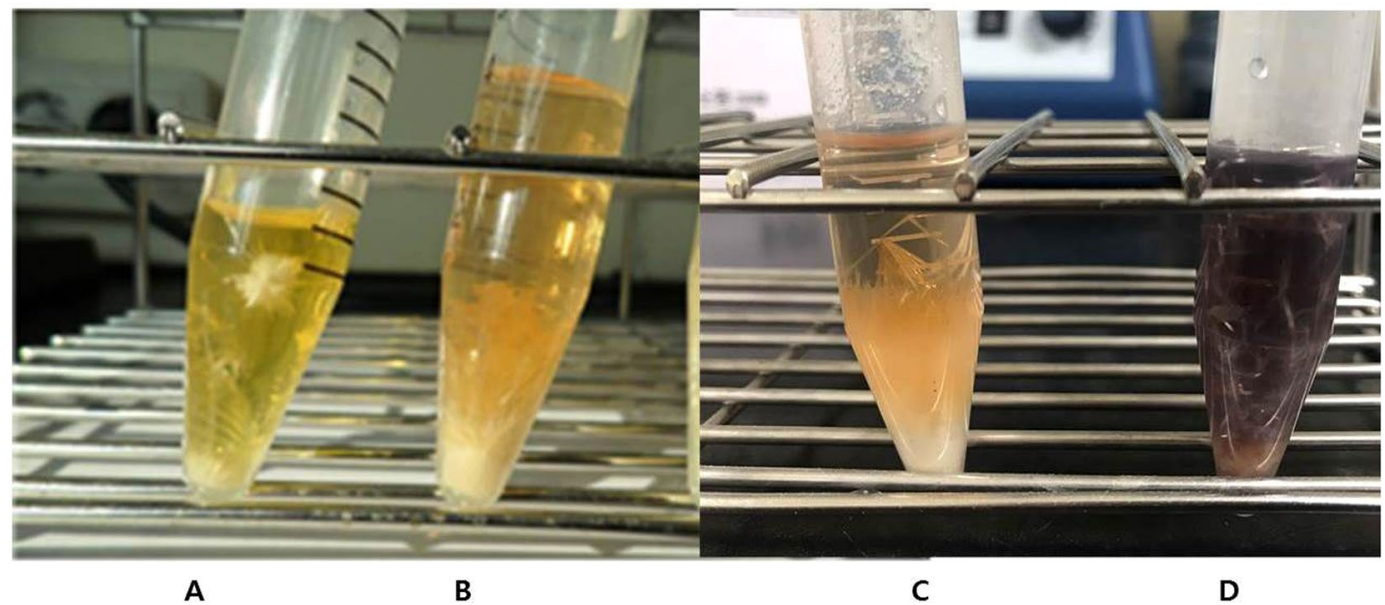

Figure 2. Crystals of tryptolines obtained from the aqueous Pictet-Spengler reaction of tryptamine with four different aldehydes facilitated by L-tartaric acid; (A) (1), (B) (4), (C) (2), (D) (3).

\section{Results}

We examined the substrate scope of the Pictet-Spengler reaction with four different aldehydes, as shown in Fig. 1. L-Tartaric acid facilitated the formation of colorless-crystalline tryptolines, as shown in Fig. 2. The optimum amount of L-tartaric acid was determined by carrying out the experiment with $0.1-1$ equiv. of L-tartaric acid. We 
found that 0.5 equiv. of L-tartaric acid was sufficient to give the highest yield, as the yield did not improve when using more than 0.5 equiv. of L-tartaric acid. The reaction was carried out in water, which is a cheap and safe solvent. The reaction mixture was set still until the crystals formed, and the products were filtered without any additional workup. Tryptolines 1-4 were obtained in crystalline form and in fair yields (25-45\%), and required no chromatography. The most substituted $\beta$-carboline $\mathbf{4}$ showed the best inhibitory activity against EJ cells.

1-Phenyl-2,3,4,9-tetrahydro-1 $\boldsymbol{H}$-pyrido[3,4-b]indole (1). Yield: $25 \%$ (crystalline). $[\alpha]_{\mathrm{D}}^{25}=-0.48$ $(\mathrm{c}=0.5, \mathrm{MeOH}) . \mathrm{Mp} .240 \sim 243^{\circ} \mathrm{C} .{ }^{1} \mathrm{H}$ NMR $(500 \mathrm{MHz}, \mathrm{MeOD}) \delta(\mathrm{ppm}): 7.59(\mathrm{~d}, 1 \mathrm{H}, J=8.0 \mathrm{~Hz}), 7.56-7.53(\mathrm{~m}$, $3 \mathrm{H}), 7.48-7.46(\mathrm{~m}, 2 \mathrm{H}), 7.33(\mathrm{~d}, 1 \mathrm{H}, J=8.0 \mathrm{~Hz}), 7.19(\mathrm{t}, 1 \mathrm{H}, J=8.0 \mathrm{~Hz}), 7.12(\mathrm{t}, 1 \mathrm{H}, J=8.0 \mathrm{~Hz}), 5.96(\mathrm{~s}, 1 \mathrm{H}), 3.70-$ $3.65(\mathrm{~m}, 1 \mathrm{H}), 3.62-3.57(\mathrm{~m}, 1 \mathrm{H}), 3.35-3.26(\mathrm{~m}, 1 \mathrm{H}), 3.22-3.18(\mathrm{~m}, 1 \mathrm{H}) .{ }^{13} \mathrm{C}$ NMR $(100 \mathrm{MHz}, \mathrm{MeOD}) \delta(\mathrm{ppm})$ : 137.1, 135.3, 130.6, 130.2, 129.3, 129.1, 126.3, 122.4, 119.5, 118.7, 112.1, 108.0, 56.0, 18.6. Microscope-FTIR (KBr pellet, $\mathrm{cm}^{-1}$ ) 3213 (s), 3051(w), 2904 (s), 2804 (s), 2748 (s), 2692 (s), 2675 (s), 2611 (s), 2571 (s), 2480 (w). LCMS $[\mathrm{M}+\mathrm{H}]^{+} m / z$ calcd. for $\mathrm{C}_{17} \mathrm{H}_{17} \mathrm{~N}_{2} 249.1392$; detected 249.1315 .

2,6-Dimethoxy-4-(2,3,4,9-tetrahydro-1H-pyrido[3,4-b]indol-1-yl)phenol (2). Yield: 40\% (crystalline). $[\alpha]^{25}=-2.76(\mathrm{c}=0.5, \mathrm{MeOH})$. Mp. $206 \sim 210^{\circ} \mathrm{C}$.

${ }^{1} \mathrm{H}$ NMR $(500 \mathrm{MHz}, \mathrm{MeOD}) \delta(\mathrm{ppm}): 7.58(\mathrm{~d}, 1 \mathrm{H}, J=9.0 \mathrm{~Hz}), 7.34(\mathrm{~d}, 1 \mathrm{H}, J=8.0 \mathrm{~Hz}), 7.19(\mathrm{t}, 1 \mathrm{H}, J=8.0 \mathrm{~Hz})$, $7.12(\mathrm{t}, 1 \mathrm{H}, J=8.0 \mathrm{~Hz}), 6.74(\mathrm{~s}, 2 \mathrm{H}), 5.86(\mathrm{~s}, 1 \mathrm{H}), 3.84(\mathrm{~s}, 6 \mathrm{H}), 3.74-3.70(\mathrm{~m}, 1 \mathrm{H}), 3.62-3.57(\mathrm{~m}, 1 \mathrm{H}), 3.31-3.26(\mathrm{~m}$, $1 \mathrm{H}), 3.21-3.16(\mathrm{~m}, 1 \mathrm{H}) .{ }^{13} \mathrm{C}$ NMR $\left.(100 \mathrm{MHz}, \mathrm{MeOD}) \delta(\mathrm{ppm}):\right): 163.6,139.3,133.1,129.7,128.1,128.0,124.5$, 121.5, 120.1, 116.6, 113.3, 109.7, 58.8, 56.8, 42.9, 20.4. Microscope-FTIR (KBr pellet, cm $\left.{ }^{-1}\right) 3433(\mathrm{w}), 3234(\mathrm{w})$, $3059(\mathrm{w}), 2943(\mathrm{w}), 2902(\mathrm{w}), 2800(\mathrm{~s}), 2646(\mathrm{w}), 1618(\mathrm{~s}), 1523(\mathrm{~s}), 1466(\mathrm{~s}), 1427(\mathrm{~s}), 1336(\mathrm{~s}), 1238(\mathrm{~s}), 1119(\mathrm{~s})$. LCMS $[\mathrm{M}+\mathrm{H}]^{+} m / z$ calcd. for $\mathrm{C}_{19} \mathrm{H}_{21} \mathrm{~N}_{2} \mathrm{O}_{3}$ 325.1552; detected 325.1460.

1-(4-Methoxyphenyl)-2,3,4,9-tetrahydro-1H-pyrido[3,4-b]-indole (3). Yield: 40\% (crystalline). $[\alpha]_{D}^{25}=-2.04(\mathrm{c}=0.5, \mathrm{MeOH}) . \mathrm{Mp} .242 \sim 244^{\circ} \mathrm{C}$.

${ }^{1} \mathrm{H}$ NMR $(500 \mathrm{MHz}, \mathrm{MeOD}) \delta(\mathrm{ppm}): 7.57(\mathrm{~d}, 1 \mathrm{H}, J=9.0 \mathrm{~Hz}), 7.33(\mathrm{~d}, 1 \mathrm{H}, J=8.0 \mathrm{~Hz}), 7.19(\mathrm{t}, 1 \mathrm{H}, J=7.0 \mathrm{~Hz})$, $7.12(\mathrm{t}, 1 \mathrm{H}, J=7.0 \mathrm{~Hz}), 7.07(\mathrm{~d}, 2 \mathrm{H}, J=9.0 \mathrm{~Hz}), 5.89(\mathrm{~s}, 1 \mathrm{H}), 3.86(\mathrm{~s}, 3 \mathrm{H}), 3.67-3.63(\mathrm{~m}, 1 \mathrm{H}), 3.59-3.54(\mathrm{~m}, 1 \mathrm{H})$, 3.11-3.07 (m, 1H), 3.30-3.24 (m, 1H), 3.20-3.15 (m, 1H). ${ }^{13} \mathrm{C}$ NMR (100 MHz, MeOD) $\delta(\mathrm{ppm})$ 155.9, 137.1, $131.4,130.3,122.3,120.2,119.6,119.2,117.8,115.2,111.1,107.6,51.4,39.8,18.3$. Microscope-FTIR (KBr pellet, $\left.\mathrm{cm}^{-1}\right) 3222(\mathrm{~s}), 3014(\mathrm{w}), 2902$ (s), 2790 (s), 2742 (s), 2567 (w), 1614 (s), 1516 (s), 1454 (s), $\left.14309 \mathrm{~s}\right), 1307$ (s), 1254 (s), 1180 (s), 741 (s). LCMS $[\mathrm{M}+\mathrm{H}]^{+} \mathrm{m} / z$ calcd. for $\mathrm{C}_{19} \mathrm{H}_{19} \mathrm{~N}_{2} \mathrm{O}$ 279.1497; detected 279.1364.

1-Cyclohexyl-2,3,4,9-tetrahydro-1H-pyrido[3,4-b]indole (4). Yield: 45\% (crystalline). $[\alpha]^{25}{ }_{\mathrm{D}}=-3.08(\mathrm{c}=0.5, \mathrm{MeOH}) . \mathrm{Mp} .242 \sim 246^{\circ} \mathrm{C} .{ }^{1} \mathrm{H}$ NMR $(500 \mathrm{MHz}, \mathrm{MeOD}) \delta(\mathrm{ppm}): 7.51(\mathrm{dd}, 1 \mathrm{H}, J=8.0 \mathrm{~Hz}$, $J=2.5 \mathrm{~Hz}), 7.40(\mathrm{~d}, 1 \mathrm{H}, J=8.0 \mathrm{~Hz}), 7.18(\mathrm{t}, 1 \mathrm{H}, J=7.0 \mathrm{~Hz}), 7.08(\mathrm{td}, 1 \mathrm{H}, J=7.0 \mathrm{~Hz}, 0.5 \mathrm{~Hz}), 4.65(\mathrm{~d}, 1 \mathrm{H}$, $J=4.5 \mathrm{~Hz}), 3.79-3.74(\mathrm{~m}, 1 \mathrm{H}), 3.47-3.42(\mathrm{~m}, 1 \mathrm{H}), 3.18-3.11(\mathrm{~m}, 1 \mathrm{H}), 3.11-3.07(\mathrm{~m}, 1 \mathrm{H}), 2.35-2.29(\mathrm{~m}, 1 \mathrm{H}), 1.95$ $(\mathrm{t}, 2 \mathrm{H}, J=10.5 \mathrm{~Hz}), 1.82(\mathrm{t}, 2 \mathrm{H}, J=16.0 \mathrm{~Hz}), 1.53(\mathrm{t}, 1 \mathrm{H}, J=10.0 \mathrm{~Hz}), 1.48-1.38(\mathrm{~m}, 1 \mathrm{H}), 1.32-1.20(\mathrm{~m}, 2 \mathrm{H}) .{ }^{13} \mathrm{C}$ NMR (100 MHz, MeOD) $\delta$ (ppm): 137.3, 130.0, 126.8, 122.5, 119.8, 118.6, 112.3, 107.7, 58.2, 40.8, 30.2, 27.0, 26.7, 26.6, 18.9. Microscope-FTIR (KBr pellet, $\mathrm{cm}^{-1}$ ) 3219 (s), 3053 (w), 2933 (s), 2856 (m), 2763 (m), 1620 (s), 1454 (s), 1429 (s), 1307 (s), 1221 (s). LCMS $[\mathrm{M}+\mathrm{H}]^{+} \mathrm{m} / z$ calcd. for $\mathrm{C}_{17} \mathrm{H}_{23} \mathrm{~N}_{2}$ 255.1861; detected 255.1789.

The greater the substitution on the benzyl ring of the product, the better its potency to inhibit the growth of the EJ cells. Therefore, the most substituted tryptoline $\mathbf{2}$ showed the highest inhibitory activity against the EJ cells, as shown in Fig. 3. We speculated that tryptolines may need a bulky substituent for better binding affinity to the hydrophobic pocket of the target protein. This assumption is consistent with the fact that the clinically used anticancer drugs vinblastine and vincristine are dimers of tryptolines and are thus bulkier than monomeric tryptolines.

The cytotoxicity results for tryptolines 1-4 against brine shrimp larvae are shown in Fig. 4. Tryptolines 1, 3, and 4 showed weak cytotoxicity, with $\mathrm{LC}_{50}$ values of $0.26 \mathrm{mg} / \mathrm{mL}, 0.30 \mathrm{mg} / \mathrm{mL}$, and $0.43 \mathrm{mg} / \mathrm{mL}$, respectively. However, 2, which showed the highest inhibitory activity against the EJ cells, exhibited the least cytotoxicity with an $\mathrm{LC}_{50}$ value of $1.49 \mathrm{mg} / \mathrm{mL}$. Tryptoline 2 showed no significant cytotoxicity $\left(\mathrm{LC}_{50}>1.0 \mathrm{mg} / \mathrm{mL}\right)$ against brine shrimp larvae, as opposed to the positive control $\left(\mathrm{K}_{2} \mathrm{Cr}_{2} \mathrm{O}_{7}\right)$, which showed significant cytotoxicity with an $\mathrm{LC}_{100}$ value of $0.1 \mathrm{mg} / \mathrm{mL}$, over incubation period of $24 \mathrm{~h}$. Interestingly, 2 showed the highest potency against the EJ cells but the least cytotoxicity as compared to 1,3 , and 4 .

\section{Discussion}

In conclusion, a facile method for the synthesis of biologically active tryptolines using L-tartaric acid, a simple and natural compound, is developed. L-tartaric acid facilitated aqueous Pictet-Spengler reactions with four different aldehydes. Moreover, the colorless crystalline tryptolines formed could be directly filtered to avoid further isolation steps such as extractions, column chromatography or HPLC. All of the major crystalline products showed (S)-conformer as a dominant species, based on the optical rotations we measured, although these reactions were not highly enantioselective. With respect to the anti-cancer activity of the crystalline products $1 \sim 4$, compound 2 showed the best cytotoxicity against EJ cell line. We believe that this is one of the safest and easiest methods to prepare the key intermediates in the first step of the synthesis of biologically active vinca alkaloids, especially at the industrial-scale. 

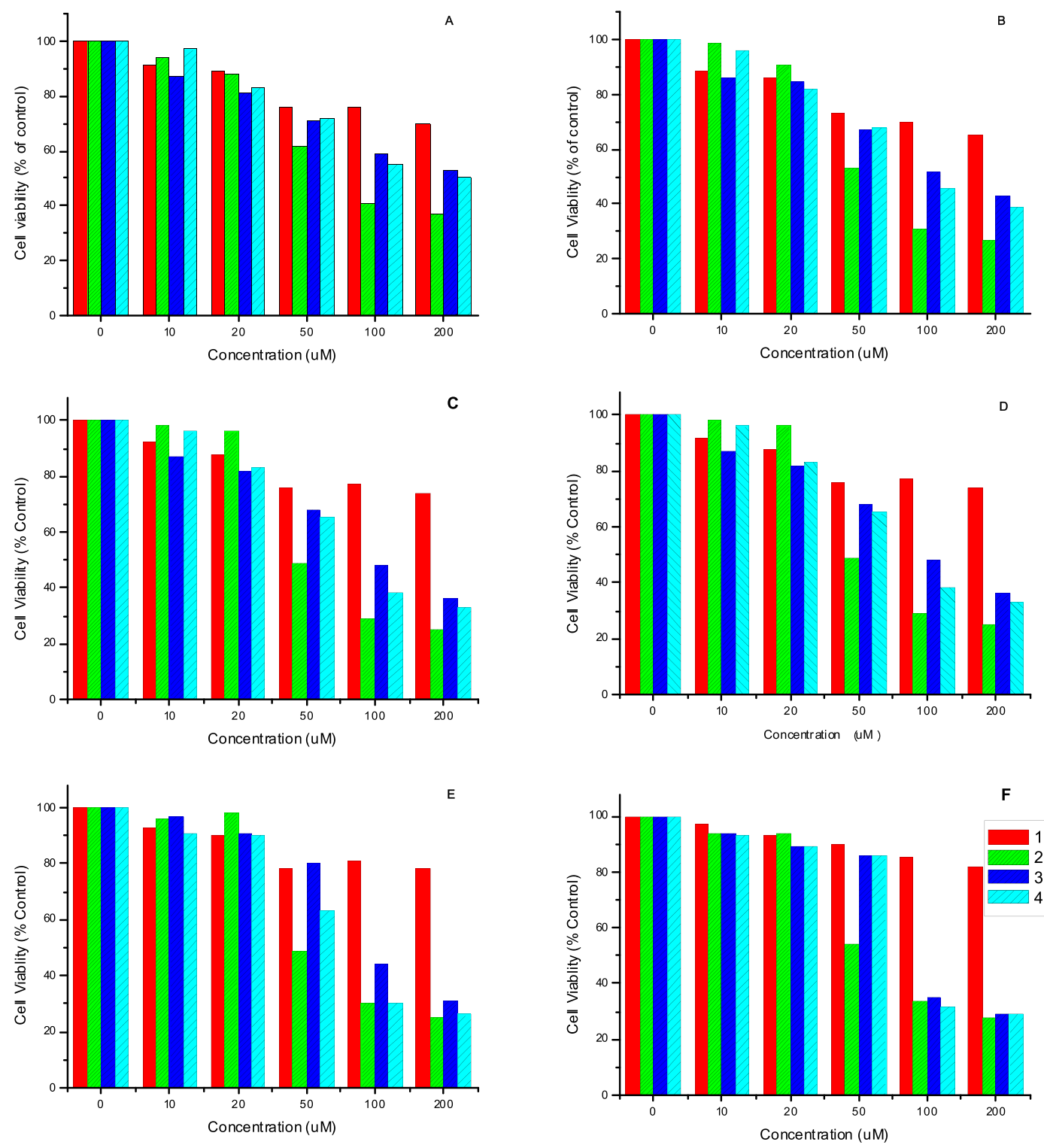

Figure 3. MTT assay to evaluate EJ cell inhibition potency of tryptolines 1-4 (red: 1, green: 2, blue: 3, and sky blue: 4) treated for (A) $12 \mathrm{~h},(\mathbf{B}) 24 \mathrm{~h},(\mathbf{C}) 36 \mathrm{~h},(\mathbf{D}) 48 \mathrm{~h},(\mathbf{E}) 72 \mathrm{~h}$, and (F) $96 \mathrm{~h}$.

\section{Methods}

General procedure for the synthesis of tryptolines. L-Tartaric acid ( 0.5 equiv., $0.5 \mathrm{mmol})$ was added to a mixture of tryptamine hydrochloride (1.0 equiv., $1.0 \mathrm{mmol}$ ) and aldehydes ( 1.0 equiv., $1.0 \mathrm{mmol}$ ) in a $15 \mathrm{~mL}$ falcon tube. The reaction volume was adjusted to $4.0 \mathrm{~mL}$ with water, and the tube was sealed. The tube was placed in a hot water bath at about $60^{\circ} \mathrm{C}$ and set still for 1-2 days until crystals were formed. The crystals were then filtered, followed by rinsing with cold water and ether.

High-resolution UPLC/QTOF/MS analysis. Ultra-performance LC/MS analysis was performed on an ultra-high-resolution Q-TOF LC-MS/MS system (Micro QTOF III, Bruker Co.) using a C18 column, with a particle size of $1.7 \mathrm{~mm}$, dimensions of $2.1 \times 100 \mathrm{~mm}$, and flow rate of $0.6 \mathrm{~mL} \mathrm{~min}^{-1}$, and an electrospray ionization (ESI) source.

MTT assay. EJ cells $\left(3 \times 10^{5}\right.$ cells/well $)$ were seeded in 6 -well plates, followed by treatment with the indicated concentrations of the compounds. After $24 \mathrm{~h}$, the used medium was removed, and a fresh medium containing $10 \mu \mathrm{L}$ of MTT solution $(5 \mathrm{mg} / \mathrm{mL})$ was added to the wells, which were then allowed to stand for $1 \mathrm{~h}$. Subsequently, the medium was removed, and the cells were treated with $0.1 \mathrm{~mL}$ of dimethyl sulfoxide (DMSO). The absorbance was measured at a wavelength of $540 \mathrm{~nm}$ using a microplate reader. The cell viability was expressed as the percentage of the absorbance value determined for the control cultures. 

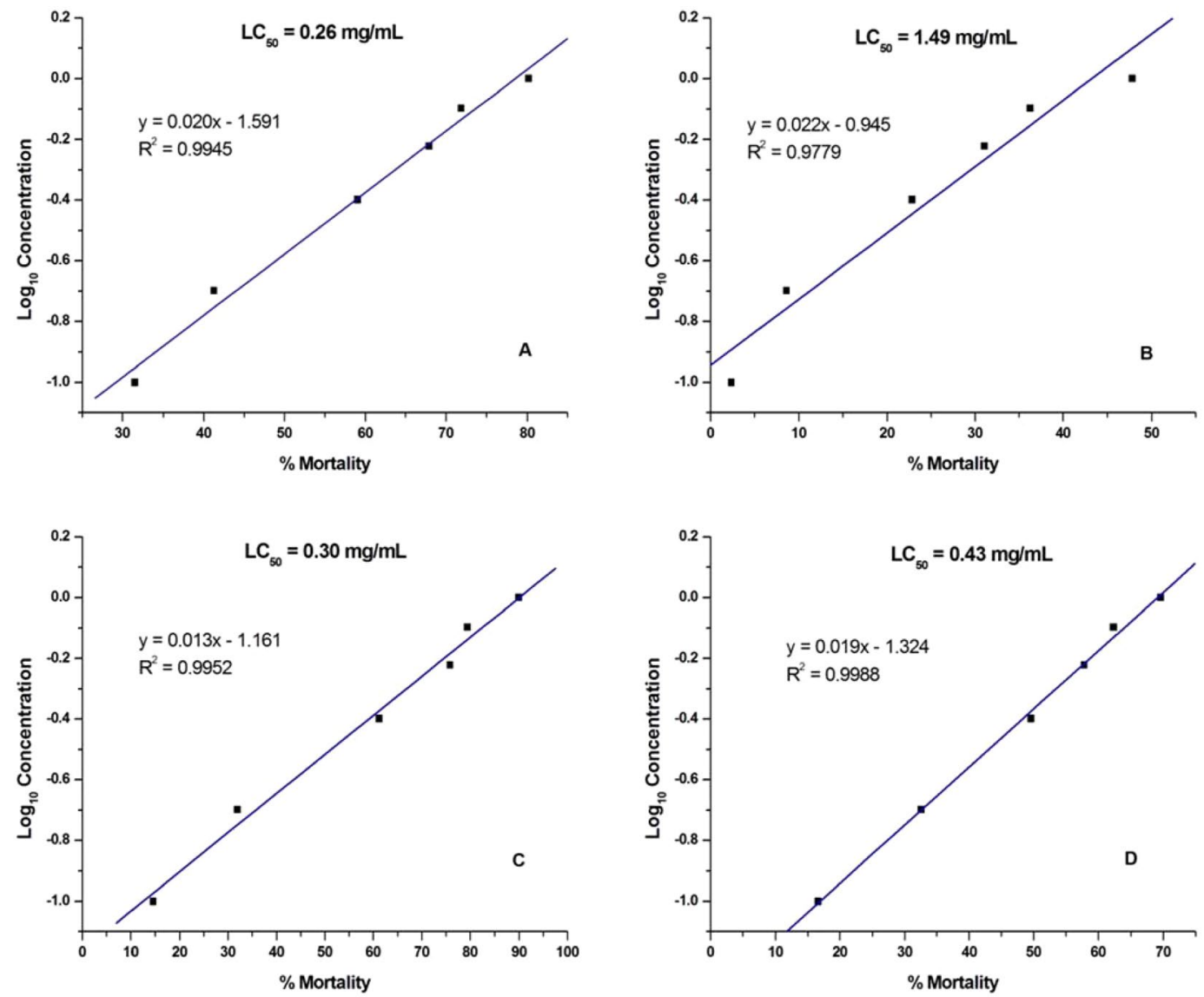

Figure 4. Cytotoxic effects of tryptolines 1(A)-4 (D) on brine shrimp larvae for an incubation period of $24 \mathrm{~h}$, determined using the brine shrimp lethality assay.

Brine shrimp lethality bioassay. The brine shrimp lethality bioassay was carried out to determine the cytotoxicity of the tryptolines (1-4). The concentration that killed $50 \%$ of the shrimps $\left(\mathrm{LC}_{50}\right)$ was determined, followed by the known method [17]. Two sets of these experiments were carried out in triplicate.

\section{Data availability}

The datasets used and analyzed during the current study are available from the corresponding author on reasonable request. Complete experimental procedures and characterization data for products are in Supporting Information.

Received: 4 July 2019; Accepted: 2 January 2020;

Published online: 23 January 2020

\section{References}

1. Laine, A. E., Lood, C. \& Koskinen, A. M. P. Pharmacological importance of optically active tetrahydro- $\beta$-carbolines and synthetic approaches to create the $\mathrm{C} 1$ stereocenter. Molecules 19, 1544-1567 (2014).

2. Lee, H. Y., Yerkes, N. \& O'Connor, S. E. Aza-tryptamine substrates in monoterpene indole alkaloid biosynthesis. Chem. Bio. 16, 1225-1229 (2009).

3. Deveau, A. M. et al. The synthesis of amino-Acid functionalized -carbolines as topoisomerase II inhibitors. Bioorg. \& Med. Chem. Lett. 11, 1251-1255 (2001).

4. Mohr, J. T., Krout, M. R. \& Stoltz, B. M. Natural products as inspiration for the development of asymmetric catalysis. Nature 455, 323-332 (2008).

5. Tayler, M. S. \& Jacobsen, E. N. Highly enantioselective Catalytic Acyl-Pictet-Spengler reactions. J. Am. Chem. Soc. 126, 10558-10559 (2004).

6. Uematsu, N., Fujii, A., Hashiguchi, S., Ikariya, T. \& Noyori, R. Asymmetric transfer hydrogenation of imines. J. Am. Chem. Soc. 118, 4916-4917 (1996).

7. Raheem, I. T., Thiara, P. S., Peterson, E. A. \& Jacobsen, E. N. Enantioselective pictet-spengler-type cyclization of hydroxylactams: H-bond donor catalysis by anion binding. J. Am. Chem. Soc. 129, 13404-13405 (2007).

8. Wanner, M. J., van der Haas, R. N. S., de Cuba, K. R., van Maarseveen, J. H. \& Hiemstra, H. Catalytic asymmetric Pictet-Spengler reactions via sulfenyliminium ions. Angw. Chem. Int. Ed. 46, 7485-7487 (2007).

9. Klausen, R. S. \& Jacobsen, E. N. Weak brönsted Acid-thiourea co-catalysis: Enantioselective, catalytic protio-Pictet-Spengler reactions. Org. Lett. 11, 887-890 (2009).

10. Szawkalo, J. S. et al. Enantioselective syntheisis of some tetrahydroisoquinoline and tetrahydro- $\beta$-carboline alkaloids. Tetrahedron: Asym. 18, 406-413 (2007). 
11. Allin, S. M., Gaskell, S. N., Elsegood, M. R. J. \& Martin, W. P. A new asymmetric synthesis of the natural enantiomer of the indolizidino [8,7-b]indole alkaloid (+)-harmicine. Tetrahedron. Lett. 48, 5669-5671 (2007).

12. Huang, D., Xu, F., Lin, X. \& Wang, Y. Highly enantioselective pictet-spengler reaction catalyzed by SPINOL-phosphoric acid. Chem. Eur. J. 18, 3148-3152 (2012)

13. Klijn, J. E. \& Engberts, J. B. F. N. Fast reactions 'on water'. Nature 435, 746-747 (2005).

14. Narayan, S. et al. On water: unique reactivity of organic compounds in aqueous suspension. Angw. Chem. Int. Ed. 44, 3275-3279 (2005).

15. Saha, B., Sharma, S., Sawant, D. \& Kundu, B. Water as an efficient medium for the synthesis of tetrahydro- $\beta$-carbolines vis PictectSpengler reactions. Tetrahedron Lett. 48, 1379-1383 (2007).

16. Kitanosono, T., Masuda, K., Xu, P. \& Kobayashi, S. Catalytic organic reactions in water toward sustainable society. Chem. Rev. 118, 679-746 (2018)

17. Desroses, M. et al. A facile and efficient synthesis of tetrahydro- $\beta$-carbolines. Tetrahedron Lett. 54, 3554-3557 (2013).

18. da Silva, W. A. et al. Novel supramolecular palladium catalyst for the asymmetric reduction of imines in aqueous media. Org. Lett. 11, 3238-3241 (2009).

19. Saeed, A. Oxa-pictet-spengler reaction in water. Synthesis of some ( \pm )-1-aryl-6,7-dimethoxyisochromans. Chin. Chem. Lett. 21, 261-264 (2010).

20. Saito, A., Numaguchi, J. \& Hanzawa, Y. Pictet-spengler reaction catalyzed by brönsted acid-surfactant-combined catalyst in water or aqueous media. Tetrahedron Lett. 48, 835-839 (2007).

21. Sasidharan, S., Darah, I. \& Jain, K. In Vivo. and In Vitro. Toxicity study of Gracilaria changii. Pharm. Bio. 46, 413-417 (2008).

\section{Acknowledgements}

This work was supported by the National Research Foundation (NRF) of Korea, NRF-2017R1D1A1B03036334.

\section{Author contributions}

H.J. Byun performed the experiments. K.H. Jung, G.S. Moon, S.K. Moon and H.Y. Lee interpreted and discussed the data. S.K. Moon and H.Y. Lee wrote the manuscript. All authors read and approved the final manuscript.

\section{Competing interests}

The authors declare no competing interests.

\section{Additional information}

Supplementary information is available for this paper at https://doi.org/10.1038/s41598-020-57911-0.

Correspondence and requests for materials should be addressed to S.-K.M. or H.-Y.L.

Reprints and permissions information is available at www.nature.com/reprints.

Publisher's note Springer Nature remains neutral with regard to jurisdictional claims in published maps and institutional affiliations.

(c) (i) Open Access This article is licensed under a Creative Commons Attribution 4.0 International

License, which permits use, sharing, adaptation, distribution and reproduction in any medium or format, as long as you give appropriate credit to the original author(s) and the source, provide a link to the Creative Commons license, and indicate if changes were made. The images or other third party material in this article are included in the article's Creative Commons license, unless indicated otherwise in a credit line to the material. If material is not included in the article's Creative Commons license and your intended use is not permitted by statutory regulation or exceeds the permitted use, you will need to obtain permission directly from the copyright holder. To view a copy of this license, visit http://creativecommons.org/licenses/by/4.0/.

(C) The Author(s) 2020 